\title{
Susceptibility of Human and Porcine Neutrophils to Hypothermia in Vitro
}

\author{
Y. SUNG, V. AKRIOTIS, C. BARKER, S. CALDERWOOD, AND W. D. BIGGAR \\ Department of Paediatrics and the Research Institute, The Hospital for Sick Children and University of Toronto, \\ Toronto, Ontario, Canada
}

\begin{abstract}
Hypothermia may contribute to serious lifethreatening infections. An experimental model has been established in pigs in order to study the effects of hypothermia on host bacterial defenses. The function of blood neutrophils from pigs and humans was examined in vitro at 37 and $29^{\circ} \mathrm{C}$. Bacterial killing of Staphylococcus aureus $502 \mathrm{~A}$ by human neutrophils after 90 and $180 \mathrm{~min}$ incubation at $29^{\circ} \mathrm{C}$ was reduced to $76 \pm 6 \%$ and $83 \pm 7 \%$ of killing at $37^{\circ} \mathrm{C}$. Porcine neutrophil killing was similarly reduced at 90 min $(72 \pm 9 \%)$ and remained significantly impaired after $180 \mathrm{~min}(52 \pm 11 \%)$. Phagocytosis of ORODP-LPS particles by human neutrophils after $5 \mathrm{~min}$ at $29^{\circ}$ $C$ was $40 \pm 5 \%$ of that at $37^{\circ} \mathrm{C}$ and only $55 \pm 7 \%$ after 15 min by which time maximum phagocytosis had occurred at $37^{\circ} \mathrm{C}$. Porcine neutrophils ingested significantly less ORO (68 $\pm 8 \%$ ) after $5 \mathrm{~min}$ at $29^{\circ} \mathrm{C}$ and reached normal values by $15 \mathrm{~min}$. Stimulation of hexose monophosphate pathway in human neutrophils for $20 \mathrm{~min}$ at $29^{\circ} \mathrm{C}$ was only $13 \pm 5 \%$ of that at $37^{\circ} \mathrm{C}$ and required $2 \mathrm{~h}$ of stimulation to reach normal values. Porcine cells were reduced to $74 \pm 9 \%$ after $20 \mathrm{~min}$ incubation and reached normal values by $30 \mathrm{~min}$. Directed neutrophil migration as assessed under agarose was impaired for both human (39 $\pm 6 \%)$ and porcine $(20 \pm 4 \%)$ neutrophils at $29^{\circ} \mathrm{C}$ compared to $37^{\circ} \mathrm{C}$. Random neutrophil migration was not affected at $29^{\circ} \mathrm{C}$ for either neutrophil type. Human and porcine neutrophil functions are compromised by hypothermia in vitro. The pig serves as a useful experimental model to study the affects of temperature on host defenses. (Pediatr Res 19: 1044-1047, 1985)
\end{abstract}

\section{Abbreviations}

HBSS, Hanks' balanced salt solution

HMP, hexose monophosphate pathway

ZAS, zymosan activated serum

ORO-DP-LPS, oil-red-O-diisodecyl-phthalate-endotoxin

Pediatric applications of induced hypothermia have extended into cardiac surgery and intensive care units. Hypothermia may be profound $\left(<20^{\circ} \mathrm{C}\right)$ and be maintained for $1-2 \mathrm{~h}$ during open heart surgery. Alternatively, hypothermia may be moderate (29$30^{\circ} \mathrm{C}$ ) and maintained for several days as part of a cerebral resuscitation protocol for severe and life-threatening brain edema. Accidental hypothermia on the other hand, may be associated with rectal temperatures of $30^{\circ} \mathrm{C}$. We, and others, have raised concern that prolonged periods of hypothermia may be accompanied by serious and life-threatening bacterial infec-

Received April 8, 1985; accepted May 30, 1985.

Address communications to W. D. Biggar, M.D., Division of Infectious Diseases, Hospital for Sick Children, Toronto, Ontario, Canada M5G 1 X8. tions (Bohn DJ, et al, unpublished data) (1-4). Evidence from experimental animals suggests that infections may not only be more frequent during hypothermia, but they may be caused by bacteria not normally considered virulent (5). Thus, since bacterial defenses are likely compromised by hypothermia, we sought to establish an experimental animal model which could examine these important questions raised by children exposed to induced or accidental hypothermia. This was essential because of technical and ethical problems relating to studying critically ill children in the intensive care setting. The pig was selected because of its many physiological, nutritional, metabolic, and anatomic similarities to humans (6). Pigs could be anesthetized, ventilated, and maintained under conditions very similar to those used clinically. Furthermore, pigs, in contrast to smaller animal models, can tolerate serial blood sampling without compromising their cardiac status and inflammatory responses. However, it is not known if hypothermia exerts a similar effect on porcine neutrophil function as it does on human neutrophils. We report herein studies which have compared the effects of hypothermia in vitro on porcine and human neutrophil functions which are considered important to bacterial defenses.

\section{MATERIALS AND METHODS}

Pig model. Pigs weighing 10 to $15 \mathrm{~kg}$ were used. The pigs were permitted water but were otherwise fasted for $12 \mathrm{~h}$ before anesthesia. The pigs were sedated with acepromazine $(2 \mathrm{mg} / \mathrm{kg}$ intramuscularly) $45 \mathrm{~min}$ before transfer to the operating room. Anesthesia was induced with a nasal facepiece and a mixture of $4 \%$ halothane in $100 \%$ oxygen and then maintained with $1.5 \%$ halothane after intubation. Under aseptic conditions, arterial and venous cannulae were inserted. Arterial pressure was monitored with a Statham arterial transducer (model 1280) and Hewlett-Packard recorder (model 7700). Arterial blood gases were monitored hourly. Core temperatures were monitored continuously with YSI Thermisters (model 43TK, Yellow Springs Instrument Co., Yellow Springs, $\mathrm{OH}$ ) placed in the rectum and esophagus and maintained at $37 \pm 0.5^{\circ} \mathrm{C}$. An intravenous glucose-saline solution was administered at a rate of $10 \mathrm{ml} / \mathrm{kg}$ / h.

Leukocyte studies. Blood samples taken into heparinized plastic syringes and processed immediately. $\mathrm{Hb}$, hematocrit, leukocyte count and differential, and blood smears were performed by standard laboratory techniques. For the experiments reported herein, blood was obtained from normothermic humans and pigs and neutrophil functional studies were done at $37^{\circ} \mathrm{C}$ and after cooling the cells to $29^{\circ} \mathrm{C}$.

Human blood neutrophils were isolated by dextran sedimentation ( $4 \mathrm{ml}$ dextran $/ 20 \mathrm{ml}$ blood). Porcine neutrophils were isolated by hespan sedimentation (American Hospital Supply Corp., Irvine, CA). The blood was sedimented and the plasma layer removed. The cells were washed twice in HBSS (Grand Island Biological Co., Grand Island, NY) and resuspended in 
HBSS to the desired concentration of neutrophils. Suspensions prepared in this way regularly contained $60-70 \%$ neutrophils.

Staphylococcus aureus 502A was the test bacteria. For these experiments, 18-h bacterial cultures were used. The bacterial culture was then centrifuged, washed twice in HBSS, and resuspended in HBSS to a concentration of $10^{7}$ organisms $/ \mathrm{ml}$.

Bacterial phagocytosis and killing was examined using the methods of Alexander et al. (7) with the exception that penicillin and streptomycin were added to the leukocyte:bacteria mixtures after $20 \mathrm{~min}$ of incubation rather than at the start of the reaction. The reaction tubes were incubated at 37 or $29^{\circ} \mathrm{C}$. The viable intracellular and extracellular bacteria were quantitated using standard dilution and pour-plate techniques. Control tubes for bacterial growth were examined in parallel at 37 and $29^{\circ} \mathrm{C}$. These contained $0.8 \mathrm{ml}$ HBSS, $0.1 \mathrm{ml}$ pooled normal human serum and $0.1 \mathrm{ml}$ bacteria.

Neutrophil phagocytosis of ORO. Neutrophil phagocytosis of ORO was examined using the method of Stossel et al. (8). A suspension of the dye ORO (Sigma Chemical Co., St. Louis, MO) and DP (ICN Pharmaceuticals Inc., Plain View, NY) was prepared by mortar and pestle. The undissolved dye was removed by centrifugation. Two and one-half milliliter of the ORO-DP suspension was sonicated with $100 \mathrm{mg}$ of Escherichia coli (OIIIB4) LPS (Difco Laboratories, Detroit, MI) in $7.5 \mathrm{ml}$ HBSS for 5 min. The final suspension (ORO-DP-LPS) was aliquoted and stored at $-20^{\circ} \mathrm{C}$ for future use.

The ORO-DP-LSP particles were opsonized just prior to use by incubating them with an equal volume of pooled normal human or pig serum at $37^{\circ} \mathrm{C}$ for $15 \mathrm{~min}$. Neutrophils were prepared as previously described and adjusted to a concentration of $6.25 \times 10^{6}$ cells $/ \mathrm{ml}$. Of the neutrophil suspension $0.8 \mathrm{ml}$ was added to siliconized $15-\mathrm{ml}$ conical glass tubes (Fisher Laboratories, Toronto, Ontario, Canada) and then placed in a shaking water bath at 37 or $29^{\circ} \mathrm{C}$. Two control tubes were incubated at $0^{\circ} \mathrm{C}$ to prevent phagocytosis, and two control tubes were incubated without neutrophils to measure any nonspecific adherence of dye to the tubes. The neutrophils were incubated for $5 \mathrm{~min}$ to reach the desired temperature, then $0.2 \mathrm{ml}$ of freshly opsonized ORO-DP-LPS particles at 37 or $29^{\circ} \mathrm{C}$ was added. At the end of each incubation period, $5 \mathrm{ml}$ of ice-cold $1 \mathrm{mM} \mathrm{N}$-ethyl-maleimide (Fisher Chemicals, Toronto, Ontario, Canada) was added to each of the duplicate tubes. The neutrophils were washed twice with ice-cold N-ethylmaleimide and then $1.0 \mathrm{ml}$ of 1,4-dioxane was added. The ingested dye was measured in a Gilford spectrophotometer at $525 \cdot \mathrm{nm}$.

Neutrophil metabolism. HMP activity was measured during phagocytosis at 37 and $29^{\circ} \mathrm{C}$ according to the method described by Holmes et al. (9). Neutrophils were prepared as previously described, except that cells were resuspended in Kreb's Ringer phosphate instead of HBSS.

Neutrophil migration. Neutrophils were examined for their ability to migrate under agarose at 37 and $29^{\circ} \mathrm{C}$ using the method described by Nelson et al. (10) and modified by Issekutz and Biggar (11).

Neutrophils were isolated as described and resuspended in MI99 (Gibco, Grand Island, NY) to a concentration of $5 \times 10^{6}$ cell $/ \mathrm{ml}$. Into duplicate outer wells, $10 \mu \mathrm{l}$ of the chemotactic factor was added. The chemotactic factor was ZAS. The agarose plates containing the chemotactic factors in the outer wells were incubated for $1 \mathrm{~h}$ in a $\mathrm{CO}_{2}$ incubator at $37^{\circ} \mathrm{C}$. The plates were maintained at $37^{\circ} \mathrm{C}$ or cooled to $29^{\circ} \mathrm{C}$ and the neutrophils added to the inner wells. The plates were then incubated in the $\mathrm{CO}_{2}$ incubator at 37 or $29^{\circ} \mathrm{C}$ for $3 \mathrm{~h}$. After incubation, the cells were fixed by flooding the plates with methanol for $10 \mathrm{~min}$, followed by formalin. The agarose was removed and the plates were stained with $10 \%$ Giemsa (Fisher Chemicals). The distance moved by the neutrophils was measured by the leading front method with a projecting microscope (12).

Statistics. Data are expressed as the mean \pm SEM and significance was determined using Student's $t$ test at a level of $\leq 0.05$.

\section{RESULTS}

Bacterial killing. Human and porcine neutrophil killing of $S$. aureus was assessed at 37 and $29^{\circ} \mathrm{C}$ and the results are summarized in Figure 1. For these experiments, the bacteria to porcine neutrophil ratio varied between $1: 5$ to $1: 10$. At these ratios, porcine neutrophils killed greater than $95 \%$ of the bacteria inoculum over the 180 -min observation period. When more bacteria were added to the reaction tubes, the percent of bacteria killed by porcine neutrophils fell to less than $95 \%$. Human neutrophils on the other hand, were able to kill more than $95 \%$ of the bacterial inoculum when the bacteria to neutrophil ratio varied between $1: 1$ to $10: 1$. For the experiments reported herein, the bacteria to neutrophil ratio was 1:10. After 90-min incubation at $29^{\circ} \mathrm{C}$, human neutrophils killed $76 \pm 6 \%$ of the number of bacteria killed by neutrophils tested at $37^{\circ} \mathrm{C}$. After $180 \mathrm{~min}$ at $29^{\circ} \mathrm{C}$, bacterial killing improved slightly to $83 \pm 7 \%$ of that at $37^{\circ} \mathrm{C}$. When bacterial killing was assessed after 90 and $180 \mathrm{~min}$ at $29^{\circ} \mathrm{C}$, porcine neutrophils killed $S$. aureus significantly less than at $37^{\circ} \mathrm{C}$. After $90 \mathrm{~min}$, porcine neutrophils killed $72 \pm 9 \%$, the number killed at $37^{\circ} \mathrm{C}$. By $180 \mathrm{~min}$, bacterial killing remained significantly less $(52 \pm 11 \%)$ than at $37^{\circ} \mathrm{C}$. In control tubes, which did not contain neutrophils, bacterial growth was the same at 37 and $29^{\circ} \mathrm{C}$ over the 180 -min period. When cells were cooled to $29^{\circ} \mathrm{C}$ for $60 \mathrm{~min}$ and then rewarmed to $37^{\circ} \mathrm{C}$ prior to testing, bacterial killing was normal.

Neutrophil phagocytosis. The effect of hypothermia on neutrophil phagocytosis was assessed by quantitating the uptake of opsonized ORO-DP-LPS particles. By this method, one can accurately assess phagocytosis after short periods of incubation which is not possible when bacteria are used as test particles to be ingested. When human neutrophils are studied at $37^{\circ} \mathrm{C}$, the amount of paraffin oil ( $\mathrm{mg} / 10^{6}$ cells) ingested after 5 min was $0.071 \pm 0.007$. This represents approximately $60 \%$ of the total amount ingested over the $15 \mathrm{~min}$ of observation. By $10 \mathrm{~min}$ at $37^{\circ} \mathrm{C}$ neutrophils had ingested $0.098 \pm 0.012 \mathrm{mg}$ paraffin oil per $10^{6}$ cells which increased to $0.115 \pm 0.013$ by $15 \mathrm{~min}$. After this, no significant increase in phagocytosis was observed. The effect of hypothermia on ORO phagocytosis by human and porcine cells is shown in Figure 2. At $29^{\circ} \mathrm{C}$, phagocytosis by human neutrophils was significantly reduced. After $5 \mathrm{~min}$, ingestion was only $40 \pm 5 \%$ of that observed at $37^{\circ} \mathrm{C}$. Ingestion was still reduced after $15 \mathrm{~min}$ to $55 \pm 7 \%$ of that at $37^{\circ} \mathrm{C}$. Similarly, phagocytosis by porcine neutrophils was compromised at $29^{\circ} \mathrm{C}$.

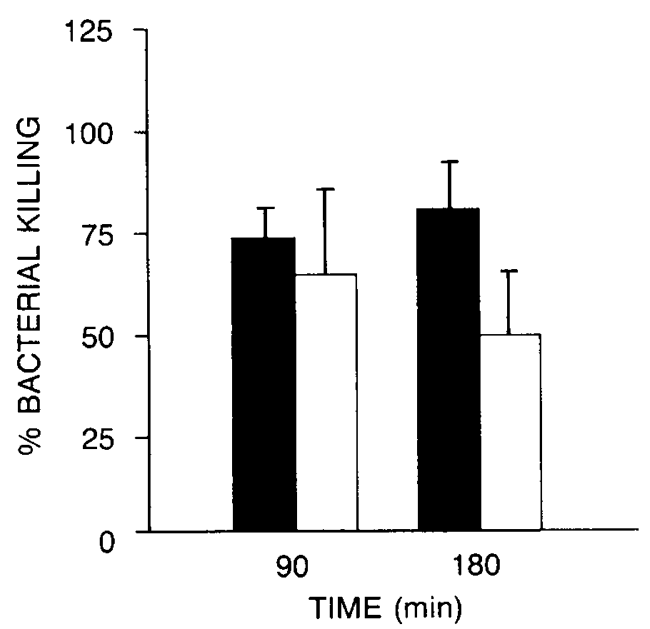

Fig. 1. The effect of hypothermia on the bactericidal activity of human and porcine neutrophils. Percent bacterial killing is calculated by dividing the number of bacteria killed at $29^{\circ} \mathrm{C}$ by the number of bacteria killed at $37^{\circ} \mathrm{C}$ and multiplying by 100 . Reaction tubes contain either human $₫$ or porcine $\square$ neutrophils $\left(10^{6}\right)$, bacteria $\left(10^{5}\right)$, and serum $(10 \%$ final concentration). Bacterial killing is assessed after 90 and $180 \mathrm{~min}$ of incubation. Each value represents the mean \pm SEM for five experiments. 


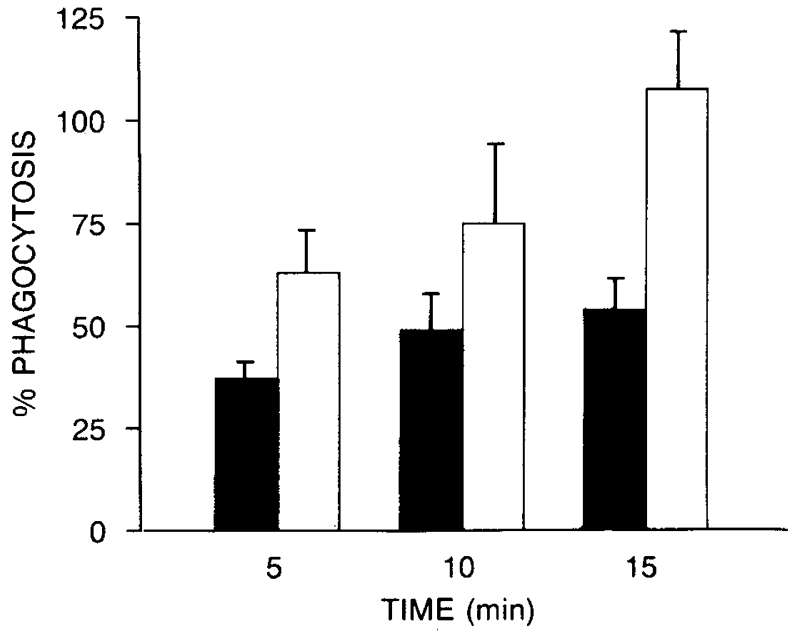

Fig. 2. The effect of hypothermia on human and porcine neutrophil phagocytosis. Percent phagocytosis is calculated by dividing the $\mathrm{mg}$ paraffin oil ingested per $10^{6}$ neutrophils at $29^{\circ} \mathrm{C}$ by the mg paraffin oil ingested per $10^{6}$ neutrophils at $37^{\circ} \mathrm{C}$ and multiplying by 100 . Reaction tubes contain either human $\square$ or porcine $\square$ neutrophils $\left(5 \times 10^{6}\right)$ and freshly opsonized ORO-DP-LPS particles. Phagocytosis was measured after 5, 10, and $15 \mathrm{~min}$ of incubation. Each value represents the mean \pm SEM for five experiments.

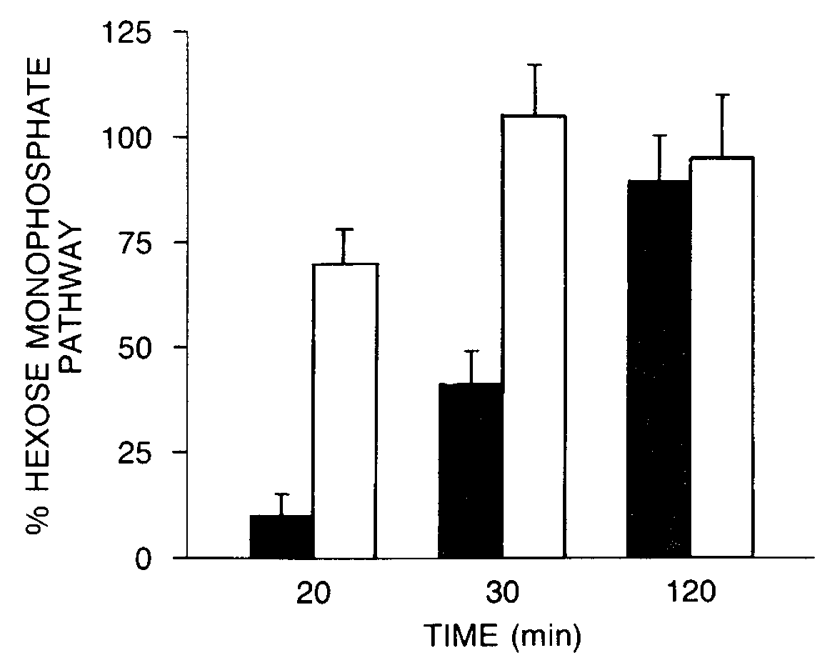

Fig. 3. The effect of hypothermia on human $\square$ and porcine $\square$ neutrophil HMP activity. Percent HMP activity is calculated by dividing the HMP activity following latex stimulation of neutrophils at $29^{\circ} \mathrm{C}$ by the HMP activity following latex stimulation of neutrophils at $37^{\circ} \mathrm{C}$ and multiplied by 100 . HMP activity is measured as the amount of ${ }^{14} \mathrm{CO}_{2}$ produced from $1-\mathrm{D}-{ }^{14} \mathrm{C}$ glucose after neutrophils were incubated with latex particles for 20,30 , and $120 \mathrm{~min}$. Each point represents the mean \pm SEM for eight experiments.

After $5 \mathrm{~min}$, ingestion was $68 \pm 8 \%$ of that at $37^{\circ} \mathrm{C}$. This increased slightly by $10 \mathrm{~min}$ and after $15 \mathrm{~min}$ phagocytosis at 29 and $37^{\circ} \mathrm{C}$ were similar. When human and porcine neutrophils were cooled to $29^{\circ} \mathrm{C}$ for 30 to $60 \mathrm{~min}$ and then rewarmed to $37^{\circ}$ $\mathrm{C}$ prior to testing, phagocytosis was normal.

Neutrophil metabolism. The HMP is an important component of the burst in oxidative metabolism which accompanies bacterial phagocytosis and is essential to bacterial killing. HMP activity was assessed at 29 and $37^{\circ} \mathrm{C}$. When human neutrophils are stimulated by latex particle phagocytosis at $37^{\circ} \mathrm{C}, \mathrm{HMP}$ activity $\left(\mathrm{cpm} 5 \times 10^{6}\right.$ cells $\left.\pm \mathrm{SEM}\right)$ after a $20 \mathrm{~min}$ exposure was $16 \pm$ $2.3 \times 10^{3}$. With longer incubation times of 30 and $120 \mathrm{~min}$, stimulated HMP activity did not increase significantly. The effects of hypothermia on HMP activity are summarized in Figure 3. At $29^{\circ} \mathrm{C}$, after 20 -min incubation with latex particles,

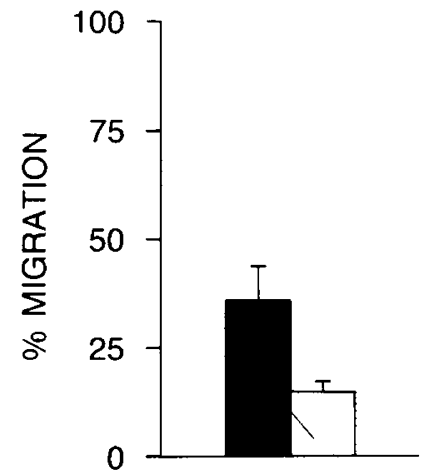

Fig. 4. The effect of hypothermia on human and porcine neutrophil migration. Percent migration is calculated by dividing the distance that human $=$ or porcine $\square$ neutrophils migrated toward the chemotactic factor, ZAS at $29^{\circ} \mathrm{C}$ by the distance traveled by cells at $37^{\circ} \mathrm{C}$. Each point represents the mean \pm SEM for five experiments.

HMP activity in human neutrophils was reduced to $13 \pm 5 \%$ of that at $37^{\circ} \mathrm{C}$. This increased to $42 \pm 8 \%$ after $30 \mathrm{~min}$ and by $120 \mathrm{~min}$, it was similar to the HMP activity of neutrophils at $37^{\circ}$ C. When porcine neutrophils were examined under similar experimental conditions, HMP activity was significantly reduced ( $74 \pm 9 \%$ ) after 20 -min incubation. But by $30 \mathrm{~min}, \mathrm{HMP}$ activity in stimulated cells was similar at 29 and $37^{\circ} \mathrm{C}$. When cells were cooled at $29^{\circ} \mathrm{C}$ for $60 \mathrm{~min}$ and then rewarmed prior to testing, HMP activity was normal.

Neutrophil migration. Neutrophil migration was examined at 29 and $37^{\circ} \mathrm{C}$. For these experiments, ZAS was used as the chemotactic factor (Fig.4). Migration by cells toward the ZAS is considered directed and migration toward the cell containing no chemotactic substance is considered random migration. At $37^{\circ}$ $\mathrm{C}$, human neutrophils migrated (distance toward ZAS measured in $\mathrm{cm}$ after magnification $\times 45) 6.60 \pm 0.5$, random migration was $1.1 \pm 0.2$. At $29^{\circ} \mathrm{C}$, directed migration was reduced $(2.7 \pm$ 0.6 or $39 \%$ ) while random migration was unchanged $(1.0 \pm 0.3)$. Porcine neutrophil directed migration was also reduced at $29^{\circ} \mathrm{C}$ being only $20 \pm 4 \%$ of that at $37^{\circ} \mathrm{C}$. As with human cells, random migration was unaffected at $29^{\circ} \mathrm{C}$. When migration was observed for longer time periods (up to $4 \mathrm{~h}$ ) porcine and human neutrophil migration at $29^{\circ} \mathrm{C}$ was still significantly reduced compared to migration at $37^{\circ} \mathrm{C}$. When the number of neutrophils was estimated by the density of cells migrating on the Petri dish after Giemsa staining, many fewer cells migrated at $29^{\circ} \mathrm{C}$ compared to $37^{\circ} \mathrm{C}$. When human and porcine cells were tested at $29^{\circ} \mathrm{C}$ over longer incubation times, the cells moved further but the number of cells migrating, as judged by the density of cells staining on the Petri dish, did not appear to increase significantly. If cells were cooled for $60 \mathrm{~min}$ and then rewarmed to $37^{\circ} \mathrm{C}$ prior to testing, directed and random migration were normal.

\section{DISCUSSION}

Severe bacterial infections are more frequent following induced and accidental hypothermia (1-4). This conclusion rests primarily on clinical experiences in humans following prolonged hypothermia at temperatures of $29-30^{\circ} \mathrm{C}$. Very little is known about the effects of controlled hypothermia on host defences in man or experimental animals. We selected the pig as an experimental model of hypothermia and host defences because it was possible to manage it in a very similar way as children who are treated with induced hypothermia. Further, the pig is recognized as having many bodily and organ functions which are similar to humans (6). The neutrophil was examined for its critical role in bacterial defences. Our experimental approach for understanding the impact of hypothermia on neutrophil function has taken advantage of in vitro and in vivo techniques. Such a combined approach is very important since the questions addressed and the findings generated by each technique can be very different. 
For example, in vitro techniques permit one to study the effect of temperature on neutrophil migration to a single stimulus. Migration in vivo on the other hand, to this same stimulus, would be influenced by many other factors, e.g. blood flow, neutrophil circulation, and vascular permeability. We described previously that hypothermia affected porcine neutrophil behavior in vivo. Reducing the core temperature of pigs to $29^{\circ} \mathrm{C}$ is associated with reduced neutrophil release from the bone marrow, increased neutrophil margination, and reduced neutrophil migration to an inflammatory site $(13,14)$. In these studies, pigs were anesthetized, ventilated, and maintained at 37 or $29^{\circ} \mathrm{C}$. As the core temperature was reduced from 37 to $29^{\circ} \mathrm{C}$ over $60 \mathrm{~min}$, the number of circulating neutrophils $\left(\times 10^{9}\right.$ per liter) fell from 6.0 \pm 0.6 to $2.3 \pm 0.3$. After this, the number of neutrophils did not increase if the temperature was maintained at $29^{\circ} \mathrm{C}$ for an additional $5 \mathrm{~h}$. Hypothermic children may also have reduced numbers of circulating neutrophils (Bohn DJ, et al, unpublished data). Stimulation of neutrophil release from the marrow by hydrocortisone sodium succinate was markedly reduced at $29^{\circ}$ C. In normothermic pigs, circulating neutrophils increased from $5.6 \pm 1.2$ to $10.4 \pm 1.2$ by $2 \mathrm{~h}$ after an intravenous hydrocortisone sodium succinate. At the same time, immature neutrophils increased from $1.7 \pm 0.3$ to $5.3 \pm 0.4$. At $29^{\circ} \mathrm{C}$, no sigificant increase in circulating mature or immature neutrophils was observed.

Accumulation of neutrophils at an inflammatory site is the next step in neutrophil contribution to bacterial defense. In vivo at $29^{\circ} \mathrm{C}$, very few of the pig's neutrophils accumulate at an inflammatory site created in the pleural space (14). The in vitro data presented herein would suggest that reduced neutrophil migration is at least partially responsible for this reduced inflammatory response in vivo. Other factors such as blood flow and vascular permeability, cell adhesion, deformability, and membrane fluidity may also be reduced at $29^{\circ} \mathrm{C}$ and contribute to compromised neutrophil migration. Humans are also thought to have reduced inflammatory responses when hypothermic (15).

In vitro studies are particularly well suited for assessing neutrophil function. Porcine and human neutrophils do not kill staphylococci normally in vitro at $29^{\circ} \mathrm{C}$. Bactericidal pathways of neutrophils may be classified as those primarily dependent on oxidative metabolism and those more dependent on the contents of lysosomal granules (16). The stimulation of oxidative metabolism is reflected by increased hexose monophosphate pathway activity. These metabolic changes are intimately associated with the partial reduction of oxygen to form bactericidal species such as superoxide, hydroxyl radicals, and possibly singlet oxygen (16). Such a pathway is of primary importance for neutrophil killing of catalase positive bacteria such as $S$. aureus. For human and porcine neutrophils, hypothermia has a significant but transient impact on cell functions. These findings likely explain in part, the increased susceptibility to bacterial infections during hypothermia. Finally, our findings indicate that the experimental pig model is appropriate for studying human disorders of host bacterial defenses.

\section{REFERENCES}

1. Dagan R, Gorodischer R 1984 Infections in hypothermic infants younger than 3 months old. Am J Dis Child 138:483-485

2. Frewen TC, Swedlow DB, Watcha M, Raphaeley RC, Godinez R, Heiser MS, Ketrick RG, Bruce DA 1982 Outcome in severe Reye's Syndrome with early phenobarbital coma and hypothermia. J Pediatr 100:663-665

3. Jackson R, Yu JS 1973 Cold injury of the newborn in Australia. Med J Aust 2:630-633

4. Mann, TP 1957 Neonatal cold injury. Lancet 1:229-234

5. Muschenheim C, Dureschner D, Hardy JD, Stoll AM 1943 Hypothermia in experimental infections. J Exp Med 72:187-196

6. Dodds WJ 1982 The pig model for biochemical research. Symposium report. Fed Proc 41:247-256

7. Alexander JW, Windhorst DB, Good RA 1968 Improved test for evaluation of neutrophil function in human disease. $\mathrm{J}$ Lab Clin Med 72:136-142

8. Stossel TP, Mason J, Hartwig J, Vaughan M 1972 Quantitative studies of phagocytosis by polymorphonuclear leukocytes: use of emulsions to measure the initial rate of phagocytosis. J Clin Invest 51:615-624

9. Holmes B, Page AR, Good RA 1967 Studies of the metabolic activity of leukocytes from patients with a genetic abnormality of phagocyte function. J Clin Invest 46:1422-1432

10. Nelson RD, Quie PG, Simmons RL 1975 Chemotaxis under agarose: A new and simple method for measuring chemotaxis and spontaneous migration of human polymorphonuclear leukocyte and monocytes. J Immunol 115:1650-1655

11. Issekutz AC, Biggar WD 1977 Influence of serum derived chemotactic factors and bacterial products in human neutrophil chemotaxis. Infect Immun $15: 212-220$

12. Orr W, Ward PA 1978 Quantitation of leukotaxis in agarose by three different methods. J Immunol Methods 20:95-107

13. Biggar WD, Bohn D, Kent G 1983 Neutrophil circulation and release from the bone marrow during hypothermia. Infect Immun 40:708-712

14. Biggar WD, Bohn DJ, Kent G, Barker C, Hamilton G 1984 Neutrophil migration in vitro and in vivo during hypothermia. Infect Immun 46:857859

15. Lewin S, Brettman LR, Holzman RS 1981 Infections in hypothermic patients. Arch Intern Med 141:920-925

16. Babior BM 1978 Oxygen-dependent microbial killing by phagocytes. N Engl J Med 298:569-668, 721-725 